\title{
Deformity of Forearm
}

National Cancer Institute

\section{Source}

National Cancer Institute. Deformity of Forearm. NCI Thesaurus. Code C35096.

Any anatomic abnormality of the arm located between the elbow and the wrist. 